Journal of Qualitative Criminal Justice \& Criminology

\title{
Beyond Basic Needs: Social Support and Structure for Successful Offender Reentry
}

Andrew S. Denney ${ }^{1}$, Richard Tewksbury ${ }^{1}$, Richard S. Jones ${ }^{2}$

${ }^{1}$ University of Louisville, ${ }^{2}$ Marquette University

Published on: Apr 01, 2014

DOI: $10.21428 / 88 d e 04 a 1 . d 95029 f 6$

License: Creative Commons Attribution 4.0 International License (CC-BY 4.0). 


\begin{abstract}
Barriers to successful reentry have long been identified as impeding an offender's ability to successfully reenter society upon release from incarceration. As a result, research has long examined what shared obstacles the majority of offenders often face upon reentering society. Much of the research identifies factors such as poor education, obtaining/maintaining employment, stable housing, and transportation as common barriers to successful reentry. By using in-depth interviews with ex-offenders deemed as successful that were conducted by two respective non-profit agencies, the present study explores what significant requirements, if any, successful offenders perceive to need and/or have experienced as lacking while attempting to successfully reenter society. Findings from this study highlight that many of the research-identified needs are not major barriers because they are often provided for by various non-profit agencies. Furthermore, successful ex-offenders overwhelmingly identify poor social support as a major barrier that oftentimes remains neglected in government and non-profit organizational programming.
\end{abstract}

\title{
Introduction
}

Offenders returning to society are a consistent concern for the general public and have troubled correctional professionals and legislators regarding how these individuals are supported once released from incarceration. With incapacitation as a primary goal of incarceration, ensuring an individual's successful transition into free society removed from a life of future criminal activity has proven to be a challenge (Kifer, Hemmens, \& Stohr, 2003; Warr \& Stafford, 1984). With approximately 688,000 offenders released from state and federal incarceration in 2011, cities are inundated with a population of individuals with poor education, inadequate job skills, and limited housing options (Carson \& Sabol, 2012; Garland, Wodahl, \& Mayfield, 2011; Horney, Osgood, \& Marshall, 1995; Maruschak \& Parks, 2012; Petersilia, 2001, 2005; Travis, 2005; Ulmer, 2001). Individuals without adequate job skills and/or sufficient education face severely limited employment opportunities and subsequent housing options. These harsh realities are further exacerbated by the label of convicted felon, a label that often carries even further restrictions on where an individual can live and/or work (Pager, 2003; Pager, Western, \& Sugie, 2009). With an estimated 4.8 million individuals under some form of community supervision, the need for continued study of such barriers to successful reentry is crucial, especially with $67.5 \%$ of released offenders being rearrested within three years of their release (Langan \& Levin, 2002; Luther, Reichert, Holloway, Roth, \& Aalsma, 2011).

While barriers to successful reentry are widely recognized today, it was not until the 1950s that examination of barriers became common (Seiter \& Kadela, 2003). In addition to problems created for by the barriers of labeling and poor skills/education, inadequate access to healthcare and substance abuse are also important obstacles for offenders re-entering society (Hammett, Roberts, \& Kennedy, 
2001; Mallik-Kane, 2008; Petersilia, 2003). Despite this wide variation in challenges facing offenders who reenter society, the barriers of education, obtaining/maintaining employment, stable housing, and transportation remain the most commonly recognized basic needs identified across the literature as barriers to successful, crime-free community re-entry (Cromwell, Alarid, \& delCarmen, 2005; Hahn, 1991; Holzer, Raphael, \& Stoll, 2004; Jucovy, 2006; La Vigne \& Parthasarathy, 2005; Listwan, 2009; Makarios, Steiner, \& Travis, 2010; Petersilia, 2003; Rutter, 1987; Seiter \& Kadela, 2003; Spjeldnes \& Goodkind, 2009; Travis, Solomon, \& Waul, 2001). It is these barriers as part of wider structural issues that often interact with one another, ultimately worsening existing circumstances that stand today as widely accepted challenges to successful re-entry (Turanovic, Rodriguez \&Pratt, 2012). When such barriers remain unaddressed, the result is oftentimes recidivism.

A majority of individuals entering incarceration, whether jail or prison, are likely to come from economically and/or socially disadvantaged backgrounds (Fergusson, Swain-Campbell, \& Horwood, 2004; Pettit \& Western, 2004). Furthermore, these individuals are likely to come into jail or prison suffering from an alcohol and/or substance abuse problem (Belenko, 2002; Belenko \& Peugh, 2005). Individuals who make up the vast majority of incarcerated offenders are also not likely to have obtained completion of General Educational Development (GED) and may have an unstable, if any, legitimate employment history (Crayton \& Neusteter, 2008; Greenberg, Dunleavy, \& Kutner, 2007). Approximately $40 \%$ of inmates who entered prison without having completed at least a GED or high school diploma were also unemployed upon entering (Harlow, 2003). With incapacitation as the primary goal of incarceration, once these individuals enter into incarceration, many issues believed to have influenced their proclivity to commit crime often go unaddressed (Kifer et al., 2003). These unaddressed needs are even further neglected because of rising costs of incarceration, resulting in a reduction of programming developed to address these issues (i.e., education, vocational training, etc.). Throughout the 1980s, the Get Tough on Crime approach led to a substantial increase in the number of individuals incarcerated at both the federal and state levels. Between 1980 and 2009, there was an increase of individuals incarcerated from 319,598 to 1,524,512, representing a $377 \%$ increase (U.S. Department of Justice, 2009). Furthermore, the annual corrections budget for federal and state correctional systems increased from $\$ 20$ billion (1982) annually to $\$ 74$ billion (2007), a $270 \%$ total increase (U.S. Department of Justice, 2009). Because of this population increase, housing and medical care provided for these offenders placed significant strain upon respective correctional budgets. Consequently, various programming meant to address the needs of offenders and increase the chances of successful reentry were cut or eliminated entirely (Cadue, 2010; Tewksbury \& Taylor, 1996). For example, the Kansas Department of Corrections lost $70 \%$ of both its treatment and educational programming in 2008 alone from budget cuts (Cadue, 2010). With these substantial financial cuts and/or elimination of programming opportunities, offenders being released from incarceration are in no better or perhaps even worse condition than when they initially entered incarceration. Once 
released, offenders often return to impoverished areas, and this places further financial and social burdens on such communities.

The vast majority of individuals released from incarceration have no prearranged housing secured (Raphael, 2011). Additionally, areas where offenders return to are likely to be economically disadvantaged areas with little to no employment opportunities, inadequate housing options, and social connections prior to their incarceration (Krivo \& Peterson, 2004; Raphael, 2011; Sampson \& Raudenbush, 1999; Sampson \& Wilson, 1995). Such issues as resource deprivation and low collective efficacy establish an environment conducive for higher levels of criminal behavior while simultaneously are impacted by the effects of such behavior (Sampson, Raudenbush, \& Earls, 1997; Turanovic et al., 2012). Therefore, offenders attempting to successfully transition into society face enormous barriers that likely contributed to their incarcerated offense initially and find themselves in no better shape to effectively manage challenges because they were faced with limited-to-no programming opportunities while incarcerated.

Despite nearly seven decades of research which examine barriers to successful re-entry, there still exists a need to study what obstacles remain for an individual attempting to successfully reenter society. Furthermore, there is a continuing need to understand what perceived and actual barriers may exist for those who are considered successful when re-entering society. The present study examines what perceived and actual challenges offenders have experienced when re-entering society (those offenders who have been deemed as successful by two respective offender-based non-profit organizations). This study can potentially result in a more comprehensive understanding of what barriers exist for all offenders, whether they are successful or not, as they attempt to successfully reenter society. This paper provides an overview of the prior literature pertaining to barriers for successful reentry (i.e., education, obtaining/maintaining employment, stable housing and transportation), followed by what successful offenders identify as perceived/ actual obstacles for reentering society, and a presentation and discussion of potential policy implications.

\section{Barriers to successful reentry}

\section{Education}

Poor education and/or limited access to educational opportunities are the first of the four basic needs serving as barriers affecting an offender's successful reentry into the community. While accurate statistics are difficult to come by regarding inmate education-levels, from 1997 to 2004, the percentage of state and federal prisoners who had a high school diploma or GED increased slightly from $61 \%$ to $65 \%$ when compared to $82 \%$ in the general population of the US (Crayton \& Neusteter, 2008; Greenberg et al., 2007). Perhaps more important than graduation rates, the National Institute for Literacy (2001) found that 7 in 10 inmates operate at the lowest levels of mathematical and prose literacy; they struggle at reading basic media such as brochures and newspapers or computing basic mathematical 
calculations (ETS, 2013). Overall poor levels-of-education have also been attributed to offenders as a reason for their inability to obtain employment upon release, making reentry yet more stressful and difficult (Holzer et al., 2003; Jucovy, 2006; Seiter \& Kadela, 2003). With poor education as a prevalent hindrance among offenders, this disadvantage not only limits one's options when seeking employment, but even impedes the ability to learn new skills to secure or maintain employment, thus compounding with the second common barrier to reentry success, obtaining and maintaining employment.

\section{Obtaining/maintaining employment}

The second of the four research-identified basic needs of offenders is obtaining and maintaining employment. Having a criminal record and the resulting stigma of being an offender can serve as a major barrier to obtaining employment (LeBel, 2012; Pager, 2003). As a collateral consequence of offending, stigma associated with offending and being an offender drastically impacts an offender's likelihood of securing employment upon release. In a 2001 survey of employers, $60 \%$ reported being apprehensive when considering hiring an individual with any type of criminal record (Holzer et al., 2003). Furthermore, Pager et al. (2009) reported that a criminal record reduced the overall likelihood of a former inmate receiving a call-back for a job interview by $50 \%$.

One primary reason why employers refrain from hiring ex-offenders is that legislation in many states restricts offenders from obtaining licensure for approximately 800 different occupations including teaching, nursing, and cosmetology (Cromwell et al., 2005; Hahn, 1991). Another primary reason why employers may be reluctant to hire an ex-offender involves legal issues surrounding ex-offenders working in direct contact with children and/or customers (Weiman, 2007). As a result of these hiring practices, between $60 \%$ and $75 \%$ of young male ex-offenders and between $25 \%$ and $40 \%$ of exoffenders as a whole remain unemployed during the first year following their release (Petersilia, 2003). Racial minority ex-offender and those suffering from mental illness have been shown to have even more difficulty obtaining employment (Baillargeon, Hoge, \& Penn, 2010; Mallik-Kane, 2008; Miles, 2004; Solomon, Kachnowski, \& Bhati, 2005). Now that employers have increased access to criminal records via online companies who specialize in background checks, it is safe to assume that this obstacle will remain in coming years (Kurlychek, Brame, \& Bushway, 2007; Weiman, 2007).

When offenders are less educated and struggle with basic reading, writing and math skills, there will likely be less desire to employ an individual with such issues. Compounding these considerations even further are legal issues associated with hiring a convicted offender that may place even further restrictions on how the tasks and in which role such individuals can be used within a business. Therefore, the combination of educational and employment issues certainly contribute to the third main barrier to successful reentry, the difficulty of obtaining and maintaining stable housing. 


\section{Stable housing}

Obtaining stable housing is the third often identified basic need for successful offender reentry but is often unmet (Corden, Kuipers, \& Wilson, 1978; Cowan \& Fionda, 1994; Harding \& Harding, 2006; Helfgott, 1997; Levenson \& Hern, 2007; Listwan, 2009; Meredith, Speir, \& Johnson, 2007; Paylor, 1995; Starr, 2002; Wodhal, 2006). Because most offenders have very unpredictable pre-arranged housing prior to their release from incarceration, those who do secure housing often do so in an impoverished neighborhood and/or community where they lived prior to their incarceration (Krivo \& Peterson, 2004; Raphael, 2011; Sampson \& Raudenbush, 1999; Sampson \& Wilson, 1995). Even if they return to familiar areas, ex-offenders are still faced with the stigma of being an offender, and this, compounded with limited/poor credit and rental history, further impacts their ability to secure and maintain stable housing (Clark, 2007; Harding \& Harding, 2006; Helfgott, 1997). Many communities in which exoffenders return often suffer from limited employment opportunities, thus exacerbating and simultaneously contributing to two identified needs serving as barriers to successful reentry (i.e., obtaining/maintaining employment and stable housing).

\section{Transportation}

The fourth frequently identified basic need that is a barrier to successful reentry is a lack of transportation. Impoverished neighborhoods and/or communities that often serve as the only feasible housing options to ex-offenders typically have either poor or limited access to reliable transportation (Luther et al., 2011). This limited access to and/or unreliable transportation has been shown to make those ex-offenders who are employed fearful that they will miss work, lose their job, and ultimately violate conditions of their parole (Garland et al., 2011). Furthermore, those exoffenders who are employed-likely outside of their impoverished neighborhoods/communities-often must rely upon unpredictable public transportation to maintain their employment which further jeopardizes their chances of meeting the basic need of maintaining stable employment (Raphael, Stoll, Small, \& Winston, 2001; Visher, La Vigne, \& Travis, 2004).

Ultimately, it is the culminating impact of poor education, obtaining/ maintaining employment, stable housing, and transportation that impedes the recently released offender's ability to successfully transition back into society. No single barrier can be isolated as being the sole cause for recently released offenders' reentry struggles, but each has an interactional effect. It is this interactional effect that makes offender reentry such a difficult issue to address. Furthermore, structural issues exist within many of these impoverished neighborhoods and/or communities that further create barriers to successful offender reentry (Sampson, et al., 1997; Triplett, Gainey, \& Sun, 2003; Turanovic et al., 2012). Despite governmental and non-profit organizations' attempts to address the above barriers to successful reentry, offender reentry continues to remain a largely unsuccessful and expensive task. 


\section{Current status of offender reentry and programs}

In 2012, there were 1,900 offenders being released from state and federal correctional institutions each day with 4,814,200 adults under some form of community supervision (Maruschak \& Parks, 2012). This is a substantial population of offenders who are being tracked by correctional officials who must hold them accountable and encourage them to refrain from crime. Since research began on offender reentry in the 1950s, research has shown the four basic needs (i.e., education, obtaining/maintaining employment, stable housing, and transportation) as being essential to successful offender re-entry (Seiter \& Kadela, 2003). As a result, programming has been specifically developed to address each of these four basic needs. One example of ma jor programming designed to address these four basic needs is the Second Chance Act of 2007 that cost approximately $\$ 25$ million to implement. Numerous other programming opportunities have also been developed at the local level to address these identified needs. In a 2009 survey of 79 major cities throughout the U.S., $72 \%$ of cities surveyed partnered with private organizations to provide re-entry services to ex-offenders, and $96 \%$ of those cities partnered with local non-profits, $81 \%$ with faith-based organizations, and $69 \%$ with neighborhood-based organizations (The United States Conference of Mayors, 2009). Additionally, 93\% of those cities offered employment services, $80 \%$ offered housing services, and $75 \%$ offered educationbased services for ex-offenders (USCM, 2009). There are a multitude of federal, state, and local level programming efforts in place throughout the United States designed to assist offenders in the process of reentry. Most of these programs are relatively small and geographically restricted which ultimately focus on only one or a small set of offenders' needs. Evaluations of reentry programs show that some programs work well, others not so well (Visher, Winterfield and Coggeshall, 2005). However, what is important to recognize is that there are programs offered and despite numerous efforts to identify best practices (Petersilia, 2004; Taxman, Young, Byrne, Holsinger \& Anspach, 2002), many programs remain unfocused and of questionable efficacy.

Despite decades' worth of research and numerous programming opportunities aimed at addressing these four basic needs, two-thirds of all offenders released from incarceration are still rearrested within the subsequent three years (Langan \& Levin, 2002; Luther et al., 2011). Furthermore, Pew/ ASCA (2011) surveys found that between 1999 and 2004, the recidivism rate for committing a new crime or crimes rose by $11.9 \%$, despite a drop in the percentage of technical violations (PCS, 2011). This occurrence results in added costs to re-process and house these offenders, thus directly contributing to the $\$ 52$ billion annual correctional budget for state and federal prisons (PCS, 2011). Therefore, the expansion of research into other areas affecting successful offender reentry beyond the four commonly identified basic needs is crucial to both fully understanding what it takes for an offender to successfully reenter society and for altering re-entry programming accordingly to ultimately improve recidivism rates. 


\section{The present study}

Traditionally studied components of successful reentry (i.e., education, employment, housing, and transportation) play a vital role in determining the likelihood for success, but the emphasis on these factors has neglected the role that other aspects may play in influencing offender reentry success, and more must be done to address high rates of recidivism. Study of components beyond the four basic needs previously discussed will help scholars and practitioners have a broader and more comprehensive understanding of the role that other factors may have in reducing individuals' chances for recidivism. The goal of the present study is to identify any significant needs that successful offenders have experienced in making a successful community reentry. Findings from this study will assist public, private and non-profit offender reentry program administrators to understand other needs that must to be taken into consideration when developing offender re-entry programming.

\section{Methods}

The current study involves one-on-one interviews of former offenders who successfully transitioned back into society. Additionally, these individuals were active participants in Prison Fellowship and a second non-profit organization, Project Return, in Milwaukee, Wisconsin. Project Return is designed to assist offenders with securing employment, housing, and other basic survival needs upon release. Responses collected reflect what former offenders who successfully transitioned back into society recognized as being necessary components for preventing recidivism. Data collection took place between the late spring and early summer of 2004.

\section{Overview of the programs}

Respondents for the present study were active in both of the two similar, yet distinct programs. The first, a branch of Prison Fellowship, is a non-profit, Christian, faith-based ministry located throughout the US that operates both inside and outside of prisons. Prison Fellowship seeks to provide offenders with a social support system of fellow offenders and stresses the importance of surrounding current and former offenders with a Christian community that emphasizes mentorship and accountability. The second program, Project Return, is also a faith-based nonprofit organization designed to provide various services to released offenders. Some of the specific services offered include assisting recently released offenders with résumé development, transportation needs, and referral to temporary work agencies for potential employment opportunities.

\section{Participants}

Participants in both organizations were former offenders who had been incarcerated in jail or prison at some point in their lives. All participants were considered by each respective organization to be successful former offenders; they met the criteria of having been released from incarceration for a minimum of three years and had no known new arrest(s), conviction(s), or parole violation(s). A total 
of 19 participants were interviewed in the present study, including both male $(n=14)$ and female $(n=5)$ offenders. Interviewees' offenses encompassed property, sex, drug and violent offenses. Participants included both those still under formal supervision (i.e., probation or parole) and those who had successfully completed these requirements. - A current age of each respondent was not collected; however most respondents were between 40 and 60 years of age. Participants from Prison Fellowship actively knew and socialized with one another, whereas participants from Project Return did not. Pseudonyms were assigned to the respondents in order to conceal their identities.

\section{Data collection}

Data for the study were collected via face-to-face interviews with offenders from the two organizations identified and previously described. Interviews were conducted in a private setting by the third author and averaged between one and three hours. A semi-structured interview guide was implemented to navigate discussion around key themes. The interview guide focused on the following themes: offender education level, sentence length, supervision status, family life, incarceration experience impact on family, reasons for choosing the respective organization, role of religion in one's life, and experience re-assimilating into society. Interviews were audio-recorded and then transcribed in full.

\section{Data analysis}

Transcripts were analyzed using content analyses and principles of analytic induction of a grounded theory approach to identify key themes and concepts (Charmaz, 1983, 2006). Once themes emerged, transcripts were reread multiple times to ensure accuracy and completeness of each identified theme. Each subsequent reading focused on a specific theme (i.e., no substantial difficulty finding assistance with basic needs, poor social support from family/friends pre-/post-incarceration, and struggles adapting to an unstructured society). Results reflect the main themes and concepts of the data.

\section{Results}

Since the goal of the present study is to identify any significant needs that successful offenders have experienced in making a successful community reentry, the specific focus went beyond the components traditionally studied (i.e., education, employment, housing, and transportation difficulties). The primary themes that emerged were that no substantial difficulties exist in securing most necessary resources (i.e., obtaining employment, housing, and transportation) for most offenders; there is poor social support system present both pre- and post-incarceration; and offenders struggle with adapting to an unstructured society from the effects of institutionalization. $\stackrel{2}{2}$ Findings suggest that parole requirements that emphasize gaining employment, housing, and transportation are fairly easily obtained through a variety of public, private, and non-profit organizations; however, social support persists as an issue even for offenders being provided other basic needs when returning to society. 
Findings overwhelmingly demonstrate that often-identified obstacles to re-entry in prior research are seemingly not as difficult as has been suggested. $\underline{3}$ Offenders discussed accessing both employment and housing with relative ease through both organizations and personal contacts. Among the four most commonly identified needs, transportation was reported as somewhat more difficult to secure, but was also adequately provided by the two non-profit social service agencies. However, a former offender's need for social support within the community was strikingly clear. Among the most frequently expressed desired forms of social support were a mentor to guide them to make everyday decisions, peers with whom to share struggles, and a support system to hold them accountable for their lifestyle and behavior. Individuals typically filled these voids through programming opportunities offered by faith-based offender ministries. The overarching theme present is that individuals reintegrating into society need structure in all aspects of their lives beyond the rules imposed by parole restrictions, even when they are provided the four most commonly identified needs across the literature. Therefore, less emphasis needs to be placed upon traditionally identified components for successful re-entry; the programming must go beyond securing employment, education, housing, and transportation to meet the need for expanded social support in the form of a community environment providing accountability to all participants.

\section{Ease of obtaining basic needs}

Previous reentry research and related programming have consistently emphasized the importance of recently released offenders obtaining employment, stable housing, and reliable transportation to facilitate successful re-entry and reduce the likelihood of recidivism. However, the importance and difficulties in obtaining such resources for this sample of successfully transitioned offenders was presented as only a minor difficulty. One respondent, Thomas, reflected on how he did not believe the felon label served as a hindrance for obtaining employment:

No, in fact, it is more so, in some areas it has helped me because I am mentoring right now and because of where I come from ... they probably skeptical but they do the background check and all of that stuff and even though that stuff is on there, it has nothing to do with what I'm doing.

Building upon this idea, offenders often discussed obtaining employment primarily through temporary services agencies that were made privy to the offender's status by a non-profit agency. Steven discussed finding a job through a temp agency when he said that, "when I got out, it wasn't really too difficult because at the time I had gotten out, I had got a job right away, working for a temporary job agency." Another individual, Matthew, previously incarcerated for homicide, built upon the prior notion of obtaining employment through a temporary employment agency, and how once he initially obtained employment he was able to further build his résumé by saying: 
when I got out, I went to [name of ministry]. I looked them up, and it took about a week to find them. I looked them up and went to them and asked them to help me fill out a résumé and a cover letter, and I just go on the payment they gave me and a voucher for clothes and stuff and when after that, it's history. From the restaurant field to a credit analyst. From a credit analyst to a program manager for a youth development center. From there a public speaker for [name of organization] in the schools doing public speaking or holding training events for the department of corrections.

Nearly two-thirds (62.5\%) of the respondents stated they gained employment initially upon release through temporary services agencies. John discussed that even though the jobs might not be the most desirable, that a convicted felon could still find employment opportunities through such agencies. Adam, a former Catholic priest incarcerated for child sex offenses, also discussed how he was hired the first place where he applied, and that he had two job offers on the same day that were several dollars above minimum wage. Similarly, Jared stated that he received a minimum of 10 different jobs through temporary services agencies and was able to choose the one he desired most, eventually remaining for nearly five years until moving into a permanent job with a non-profit faith-based organization. This subtheme of eventually obtaining work in a non-profit organization was a theme present in many of the respondents' stories. Former offenders reported that they used work obtained through temporary services agencies to pay the bills and build their résumés; however, many stated that they eventually found permanent work with a non-profit organization, typically a faith-based organization. Individuals who had worked specifically with Project Return often found permanent jobs with nonprofit agencies through contacts met while doing speaking engagements for Project Return.

There were multiple individuals (43.7\%) who were identified as working for a non-profit organization or faith-based ministry associated with offender reentry at the time that the interviews were conducted. Jared suggested an explanation for this:

I think one reason, honestly, I stayed in the non-profit sector, is that you gotta, you think that, there's a lot more understanding in non-profits and agencies like this, and even at church. You go into corporate America, that's when it hits the fan.

Julie, previously incarcerated for violating terms of a prior unknown conviction, added to this notion when she said, "I didn't have the obstacle of finding a job, not really, because that was already prepared for me too, because I was working for prison programs, so my background was an asset as opposed to being a hindrance." At least for these successful individuals, their status as a felon does not function as a stigma within a selected segment of the non-profit community. However, their status as a felon is a realized potential impediment if such opportunities were not available. Even though the nonprofit organizations are largely responsible for connecting individuals to temporary services agencies 
and/or employing them within their own organizations, they are also largely responsible for providing housing for recently released offenders.

The vast majority of offenders also reported few, if any, substantial difficulties securing housing upon release. Fully $40 \%$ of interviewees initially resided at a halfway house upon their release from incarceration, with many others initially obtaining housing via assistance of friends within churches or other non-profit social service agencies. One female respondent, Audrea, who was convicted for operating an escort service, mentioned that through her involvement in a church, she was able obtain a house on her second day of release and was even able to pay for her rent at her apartment and other bills when she says:

[S]ince prison there was one day that I needed to pay a $\$ 500$ phone bill and $\$ 500$ in rent, plus my electric bills. I needed about $\$ 1000$ to $\$ 1200$. I was on my face, $\$ 1200$ poured into my apartment in two days. Out of nowhere, out of nowhere, you know, those are my miracles.

Julie stated that she, also, had little difficulty finding a place to live. "I didn't have the problem of finding a place to stay because that was already prepared for me." Steven, who served nearly 18 years for two counts of robbery, discussed how his temporary stay in a homeless shelter allowed him to save money to get an apartment. "It was cool because I didn't have to pay no rent where I was and my food was taken care of so I actually was just banking my money and that kept me going."

While employment and housing seemingly came relatively easily, transportation was typically a more difficult resource to obtain. Transportation is most important to ensure that individuals are able to travel to and from work. Although many individuals discussed having difficulty obtaining transportation initially, it usually was provided via a non-profit agency or a social contact initiated through the assistance of a ministry. In these offenders' experiences, a non-profit agency provided free bus tickets for individuals to travel to and from work while some of the temporary job agencies provided shuttle vans for their employees.

The importance of employment and housing access was not problematic for those acknowledged as successful former offenders. However, whereas these basic needs were largely provided for and undoubtedly contribute to these offenders' success in re-entry, they are not the only issues identified as necessary and important.

\section{Poor social support}

Even though these individuals reported relative ease in obtaining many of the emphasized necessary resources (i.e., employment, housing, and transportation), respondents did discuss difficulty with securing other, often less-emphasized, needs. Individuals remarked that reentry programs did not provide for other key needs ranging from a social support system to accountability in an unstructured 
environment. However, the lack of a strong social support system was the most frequently mentioned need absent in reentry programs. Specifically, even after having the basic needs provided for them, individuals still reported that they needed social support.

Respondents discussed facing enormous difficulties in finding consistent and reliable social support from peers and/or family members throughout their lives. This lack of assistance can include moral and financial support in addition to trust. An example of an individual who did not have the needed family support throughout her life, Linda discussed running away from home at the age of 9 and joining a gang because of her abusive father. She would often commit a new offense just to escape her home life by becoming institutionalized. Audrea became a prostitute at the age of 19 to support both herself and her child because she found no other viable avenues for financial help. Another respondent, Thomas, discussed some of the difficulties with trust growing up because when he was age six and his brother was eight, they were raped by a family friend who attended his church. It is through life experiences with peers, family members, and other individuals where unreliable social support can surface and often serves as the reported impetus for individuals to begin their criminal careers. These individuals do not feel that they have a social network of family or friends who can provide moral and/ or financial support that may keep them from engaging in delinquent and/ or criminal behaviors. As a result, they continue to participate in a criminal way of life because of the lack of these social support systems. Although respondents discussed difficulties with consistent and reliable social support from peers and/or family members throughout their lives, the importance or at least the recognition of the value and need of such usually did not manifest until after they were incarcerated and/or reentering society. They expressed the desire to belong to something, to be a part of a community, and above all, to feel like they had a purpose in life. However, the nature of or the legal restrictions imposed upon many respondents due to their offense(s) often served as a barrier for continued social support. Furthermore, such legal restrictions can obstruct any potential for reconciliation.

The first subtheme that emerged regarding the lack of social support centered on many interviewees feeling ostracized from family and/or friends either due to the nature of their offenses or because of sanctions resulting from their offense. One example is Thomas, who was incarcerated for a sex offense with a minor he mentored at church-ironically, the same offense he cited as being a victim of.

I have difficulties in people that I once knew, you know. Because of all of the hate mail that I received and I don't know why I did read them all ...one of my brothers wrote me ... at least twice a month and I could call him anytime and my sister [her name] wrote me every week. I have three other sisters that weren't writing at all. I think they wrote me twice and I didn't like nothing they said. 
Similarly, yet not related to a sexual offense, Paul referenced not being allowed contact with his exwife and children after a domestic violence incident.

I wanted to, but see actually according to the court, I'm not allowed to ... I have a court order against contacting or talking to by any means, first party, second party, third party ... with my children, no matter their age as long as I am on parole or probation or ex-wife.

As Thomas and Paul's comments demonstrate, it is not only the nature of one's offense(s) that may isolate them from family support; it can also be parole restrictions as well. Building upon this notion, a former Catholic priest, Adam, once incarcerated for sex offenses with several minors that included a family member, reiterated difficulties resulting from offenses.

I had some family support, um, but people didn't understand and that was rough. That was understandable, I guess, you know, and they didn't know what to do or what to say, and because one of my victims was a family member, it was much more difficult with the divisiveness within the family.

Linda also discussed not being able to maintain contact with her children during incarceration due to her offense and the lack of subsequent family support. "I got a few letters from a few people ... I would go see my grandfather at an old folks home and spend time with him ... Other family members ... out of sight out of mind." Aaron, convicted of multiple drug offenses, discussed his poor relationship with his father and how it affected his prison stay. "My mother, my sister, you know, they stayed for support of me. I never seen my father. He never came up. I was bitter about that ... He wouldn't send me no money. He didn't do nothing." Such experiences demonstrate that although offenders may have had some contact from some family members, much of the contact was unreliable or strained due to past family relations, their offenses, or certain formal restrictions.

Isolation does not only arise from the actions of others, however. Some offenders reported choosing to isolate themselves from any fragment of family support possible for a variety of reasons. One example is John, who served approximately 20 years for an undisclosed offense; he stated that he cut off his contact with family once he realized they could no longer assist him. "Mine was very limited um cause I cut off all my support, I cut off most of my contact with the people from outside ... I came to the realization that they could not help me and so I just cut off that support."

Similarly, Charlie reported a comparable act.

I decided, and I told my wife - she was a very special person-but she had to live her life too. In order for me to do easy time, and to make it easy on her, I asked her would she get a divorce ... that was the right decision because I didn't want to think about the outside world. And because of my stupidity, I didn't want my family paying for it. 
Steven also discussed how he made the decision to cut all ties to friends and family because he found the looming sentence and potential restrictions too discouraging.

I'd write letters sometimes and it was a situation where I didn't really think that I was going to get out cause I knew I had all this time and I knew that I was so angry and upset and mad. So, I really didn't think that I was going to get out and I knew they wasn't going to give me no parole. So I really, so I consciously made a decision to cut off any kind of contact with anybody that I might have had before, before I went to prison.

Offenders like John, Charlie, and Steven found seeing family members while incarcerated too upsetting or the restrictions placed upon them too troubling and elected to manage such stress through a focus on doing their time without outside distractions. Although some offenders might choose this option, the majority of offenders did not have the luxury of remaining in touch with social contacts.

For a number of offenders who did desire to maintain relationships with loved ones through visitation(s), letters, and/or phone conversation(s), many discussed the difficulties introduced by institutional transfers as further hindering their ability to maintain desired social support from family and friends. Many of the social support issues, such as no or limited family visits, occurred due to institutional transfers that restricted the opportunities for friends and/or family to visit. As Thomas stated:

I was in [name of facility] and I wasn't there no more than three to four weeks and then they shipped me down to Texas and you know, they stripped me from my family contacts and everything, and it was real difficult.

Jennifer, who served five years for an undisclosed offense, also discussed this issue and how her mother would visit quite often when she was at one particular facility; however, the visits stopped when she was transferred to another facility outside of her mother's travel range. The vast majority of all respondents reported being transferred multiple times throughout their incarceration, contributing to the difficulties involved in maintaining contact with friends and family that could potentially help with incarceration and reentry. Furthermore, offenders were often released in areas near these facilities where friends and/or family were not nearby to help, if desired. Steven emphasized the need to abide by halfway house rules because he did not have family and friends in the area to help. "I don't have no family or friends in this whole state, so I can't risk being kicked out on the streets." As a result of his geographic location, he found himself hindered in his ability to connect with others. Furthermore, such isolation from friends, families and/or loved ones meant that offenders commonly needed to seek alternative means for accessing social support that could potentially have been provided by said family and/or friends. 


\section{Faith based resources filling the gap}

It is because of these issues-offense, poor family support, institutional transfers restricting mobility - that the individuals in the present sample sought social support mainly through non-profit faithbased prison ministries. Thomas said,

I just got with a certain knit group and they were Christian going to church, so I got with that group, you know, and just did my church thing and come back ... so that group just seemed to be just a real sensible group to me.

Paul continued this subtheme of the need to fit in and be a part of the community when he shared that he wanted "Somewhere I fit in, I can be of benefit. Somehow I can share something that might enlighten somebody." This statement highlights offenders needing to fill a void within their lives where they can feel useful to others. Adam, the former Catholic priest discussed the need to belong somewhere when he said, "I wanted to be loved and honored and have a position in life that raised me up from my despair." Scott also highlighted his need to feel a part of something greater than himself when he discussed the importance of faith-based prison ministries to help to fill a void of visitors during his incarceration:

I did a lot of correspondence, Bible courses. I would, I really kept my mind on that most of the time, you know. I stayed around positive people. Those were great because here you have people that have taken time out of their lives, you know. Who could be doing a million other things, but they come inside the prison trying to help me.

Julie, who was incarcerated in Minnesota after violating her travel restrictions for a previous undisclosed offense that left her family in Georgia, continued with this idea when she explained how her only visitors were volunteers of various prison ministry programs, "So mainly my visits were the different ministries that came, I participated in everything that was there, and that was all I had as far as visitors." Offenders typically come into contact with these ministries initially inside prison, and they pursue these relationships upon release because they are the only people they know with the ability to help, the only ones willing to do so, or family/friends may simply live too far away. John summarized his experience with the importance of these faith-based ministries for providing social support:

[I]t really helps and that is one of the probably missing ingredients to helping a guy reintegrate back into the community that they don't do now ... Just having that outside interaction with someone that wasn't talking to you criminally. They come in and said, 'I don't care what you did, I am not interested in what you did, but I am interested in you as a person.' It was probably one of the best things that happened to me because it allowed me to understand that just because I was locked up, there was someone that really cared about me and they weren't faking it ... I had a 
support group. I had people who were willing to work with me when I got out. Help me, you know, find a job with housing and everything else.

The themes discussed convey the variety of offenses that offenders struggle with; and struggles can be somewhat assuaged by consistent and reliable social support both while they are incarcerated and upon subsequent release and reentry. Across the present sample, offenders expressed seeking a sense of community where they felt that they could contribute and be both functional and valued members. Faith-based ministries both helped connect them with the necessary resources to survive, while simultaneously delivering a social support system that provided accountability. It is this provision of accountability that is seen as the most crucial offering for offenders as they reenter to an unstructured society.

\section{Accountability in an unstructured society}

Many of the offenders reported having extreme difficulty returning to society upon release from prison, but these difficulties were related to a perceived lack of social support and a lack of structure present in society rather than barriers to accessing survival resources. For offenders leaving incarceration - where essentially all of their basic needs are provided for them-a return to free society with none of the daily needs or tasks directly delivered to them causes the offenders to commonly experience a sense of anomie and anxiety. These emotions compound when individuals consider how, when, and where to find a routine and structure to life. In essence, the effects of years of institutionalization are met head-on upon returning to society. Such struggles include everything from knowing when to eat, how to wash their clothes, understanding how contemporary telephones operate and not knowing how to operate a personal computer or compact disc player. Most of these struggles center on managing and fulfilling the responsibilities that accompany daily living in free society. Scott, who served a sentence for burglary, provided an overview of the negative effects of institutionalization on hindering reentry success and the need to obtain new social support.

$[N]$ ot to blame it on the system because I put myself there, but when you are told everything to do, you know. When to do it, what time to do it, you don't, you know, you don't have to pay rent or none of those things, so you are really dependent, and then you are taken and saying, ok, now go out there and be independent, and if a person doesn't have it made up in their mind that they are ready to be responsible or to be independent as a total, that's when you go back to what's familiar and that's when on all of those occasions that's what I don't, went back with all my old friends.

Furthering this argument, Aaron stated, "I was institutionalized, and you know I would respond to bells and stuff because that's what I did in prison, you respond to bells and stuff and just don't happen ... soon as the bells would ring, I would move." Paul elaborated on this further. 
As a matter of fact. I wish sometimes I could go back to prison ... Well you know, it's easier. You don't have to pay bills, you have three hots and a cot. I'm told what to do, when to do it, I can work, I can live my life and I don't have to worry about responsibility.

The effects of institutionalization are especially strong for those who have been incarcerated for lengthy periods, especially those who have literally spent the majority of their life incarcerated or in some way institutionalized. As one such individual, Linda explained her experiences:

I know I started off as a kid. Um, foster homes, group homes and stuff like that, and I think my situation is different. When I started to go because I started to go into the system to get away from the abuses and things like that in my home ... a lot of the times that I went to jail was to get away from my father because he was really abusive. When I got into my teens, I look at it now, maybe I was institutionalized. So, I believe that between the age of seven-and-a-half and 18, I probably spent maybe a year-and-a-half free.

These same ideas and needs were also evident in the experiences of Paul who stated that his struggles upon re-entry when he had no real means of social support were only compounded with the unfamiliar responsibilities of living in free society:

Wouldn't I be happier just going back to prison because I have nobody. I have nobody, except me, so why am I doing this? Why am I here? Why do I have to worry about all these problems and these issues, these responsibilities? I don't want these responsibilities ... And I need to face those, but I also need people to help me face those, and I think one of the reasons I go to group is to help for that to get that kind of help to face those negative realities and to see other people and how they react and how they are dealing with life and how they are positive.

Beyond discussing the effects of institutionalization and the need for social support, this example also introduces another subtheme of the needs for structure and accountability. As Paul stated, he needed to "face those" responsibilities, "but I also need people to help me face those." Building upon the previous example of the expressed need for accountability, Adam noted, "[O]ne of the things that I realized was I needed genuine people, people who were going to say, 'what the hell did you do that for?' to 'what's going on?' you know, and I needed that to be genuine." Thomas also discussed the importance of the honest and genuine people within this environment when saying that the program "allowed me to open up more because I heard these guys being real sincere in telling things on themselves that they weren't happy with, but they were honest ... they were sharing themselves ... I wasn't too afraid to share me."

A last subtheme that emerged was that when these offenders recidivated, they typically did so with drug use once they were able to afford drugs using money from their newly obtained jobs. Here is yet 
another example of the need for structure and accountability among offenders upon release. Illustrating this issue is the case of Matthew who obtained a job as a chef of a local restaurant making approximately $\$ 45,000$ a year.

When I was working at the restaurant, you working 50-60 hours a week, you're burning. That was good money in my pocket and nothing to do with it. And I dove off, I fell off, got a little depressed and went down and ended up doing some cocaine from there.

As Matthew's words demonstrate, although he was able to obtain his degree in Culinary Arts and a relatively high-paying job, the lack of accountability and structure within his life and world was seen as directly contributing to his recidivating drug use. Charlie shared this belief that a mentor, more structure, and positive social support could have played in reducing his chance of recidivating.

I think that's where the organizations come into play in a large part in a person's life and a mentor where a mentor comes in ... you get the support group out there when you are going down to know that they are going to walk with you to help you even if your family out there isn't going to do it.

A second example to demonstrate the need for structure for those recently released is Steven's experience. He discussed that he was able to secure a job and his own apartment and still recidivated.

I had my own apartment, paying my bills, I got a ride and everything. And I was doing that for years, until ... you know what it was? I began to get bored, you know. I think that's why I really started using drugs again.

Steven's experience shows that even when an offender has the components traditionally emphasized as critical for success, he or she cannot be successful without social support and accountability, needs that the individuals found were provided by faith-based ministries. These examples demonstrate the need for an organization to assist offenders with their transitions back into society by providing structure, accountability, and social support, especially when no one else will or can do so.

\section{Discussion}

The current study addresses the struggles of offenders reentering society beyond the four basic needs typically identified in prior research. We introduce the notion that at least some offenders returning to society secure the components generally believed as being difficult to obtain and essential to successful reentry with relative ease (Hahn, 1991; Holzer, et al., 2003; Jucovy, 2006; La Vigne \& Parthasarathy, 2005; Listwan, 2009; Luther et al., 2011; Makarios, et al., 2010; Petersilia, 2003, 2005; Rutter, 1987; Seiter \& Kadela, 2003; Spjeldnes \& Goodkind, 2009; Travis et al., 2001). However, even with the main material items provided, these offenders still report struggles due to the lack of social support, accountability, and structure in free society. The need for social support and a community environment 
that provides such services and conditions leads at least some offenders to seek support through faithbased organizations.

The first main finding in this study is that especially with assistance, some offenders obtain the highly emphasized components of employment, housing, and transportation with relative ease, but continue to struggle with the social aspects of reentry even though they have these basic needs addressed. Specifically, securing a sense of support and adjusting to new routines (or lack of such) were the most common struggles successful offenders had. Offenders were able to initially secure employment primarily through temporary services agencies to which they were referred by parole officers and/or faith-based non-profit agencies. Additionally, participants of Project Return often secured permanent employment with non-profit agencies while doing speaking engagements for the organization. Furthermore, faith-based non-profit agencies often provided housing to offenders (in a halfway house), or offenders were able to find their own housing through contacts made in their new social networks arising out of faith-based organizations.

When basic needs are secured, focus should turn to the provision of social support systems. This will help offenders share with others and identify those have gone through or are currently facing similar situations. Additionally, these groups often provide individuals with a mentor who can assist recently released them on a one-on-one basis beyond what a parole officer typically does. Consequently, reentry programming needs not only to focus on providing the physical, economic and structural resources to live, but also should become more holistic by addressing the social and emotional aspects of life, as suggested by the second major finding of the need for social support upon release.

Initially appearing in the 1970s as a part of social psychology, social support and its relation to offender reentry success have increasingly become recognized as a vital component to effective offender reentry (Cohen \& Syme, 1985). In essence, social support in the offender context is having a network of family, friends, and/or community to provide financial and/or emotional support while the individual is incarcerated and as he or she transitions back into the community. Cullen (1994) established the importance of social support for offenders by creating three social support paradigms of crime/delinquency stemming from a lack of social support, deficiencies in social support related to higher and preventable crime rates, and the appeal of this approach to the general public's understanding of a good society. Ranging from sources such as professional services to informal connections including friends, family, and community, social support has also been identified as key to understanding an individual's mental health (Cohen \& Syme, 1985; Reis \& Collins, 2000; Rodriguez \& Cohen, 1998; Rook \& Underwood, 2000). Social support has also been identified as being a part of larger socialstructural factors in society that can be influenced by such issues as weak institutional support and resource deprivation (Turanovic et al., 2012). Consequently, these issues both influence 
factors leading to incarceration and also act as negative effects of incarceration, thus creating an endless cycle for an environment conducive to criminal behavior (Turanovic et al., 2012).

The second major finding of the present study is that offenders who have successfully transitioned from incarceration to society identify the need to have a social support system in place to assist with this transition. Many offenders have experienced poor social support throughout their lives which contributes to feelings of inadequacy and emptiness. Furthermore, such feelings oftentimes lead to drugs, crime, and recidivism. Additionally, offenders who do not have a new social support system may return to their old social support system of individuals who participate in criminal activities or alcohol and/or drug use. However, in the present study, individuals were able to identify faith-based offender ministries that provided them with a support system of pro-social individuals who in turn assisted them with transitioning back into society. Because of this social support system, many offenders found stable housing (beyond halfway houses or homeless shelters) and employment opportunities. Moreover, offenders located individuals who were going through similar trials and tribulations in their own lives and who could provide mutual support. Within these groups, they could ask for advice, have others hold them accountable, and who could provide a sense of belonging absent prior to their involvement with the group.

Social needs are of critical importance for successful reentry, above and beyond the traditionally considered aspects of providing recently released offenders with basic resources. Even when offenders have employment and housing, they may still be likely to recidivate if they do not have a support group to rely upon when facing social and emotional struggles. Prior studies have highlighted the connection between the salience of inmate social ties and social support with important identified factors as increased prison visitation and social capital to reduce an offender's overall likelihood for recidivism (Bales \& Mears, 2008; Mears, Cochran, Siennick, \& Bales, 2012; Wolff \& Draine, 2004). Additionally, Berg and Huebner (2011) reported that

having family ties could ultimately reduce recidivism while increasing one's likelihood of obtaining employment. These findings as well as those in the present study suggest that re-entry programming needs to offer pro-social support from others in a community atmosphere similar to those offered in faith-based ministries, especially when considering that offenders often return to a community void of adequate social support as a result of structural deficiencies. These structural inadequacies further hinder the development of adequate social support and thus contribute to high recidivism rates. Reentry efforts should be coordinated to ensure a more holistic set of services. Additionally, parole officers and social workers need to be aware of the importance of social support and programs that offer such support to further assist offenders with reentry.

The third major finding of the current study is that many offenders may be suffering from effects of being institutionalized after they return to free society. Because offenders were accustomed to being 
told what to do, where to go, what/when to eat, how to live, etc., once released, they are unsure of how to live on their own without having the basic needs provided for them along with instruction to guide their every move. As others have shown (Cromwell et al., 2005; Hahn, 1991; Holzer, et al., 2004; Jucovy, 2006; La Vigne \& Parthasarathy, 2005; Listwan, 2009; Makarios, et al., 2010; Petersilia, 2003, 2005; Rutter, 1987; Seiter \& Kadela, 2003; Spjeldnes \& Goodkind, 2009; Travis et al., 2001), prison often leads to a pattern of institutional behav ior that is detrimental to post-prison life. The struggles encountered in such situations have the potential to compound lead the offender to recidivate in the process of searching for a sense of familiarity, such as the seemingly attractive lifestyle with little-tono responsibility often found within an institutional setting.

This places the two previous findings into a stronger and more comprehensive perspective. Offenders not only need help obtaining the basic resources needed to survive, but they also need to be taught how to survive in free society without recidivating. This can be especially challenging in an unstructured, resource-deprived environment suffering from issues of collective efficacy where the offender is accustomed to living in a highly structured environment (Turanovic et al., 2012). Physical resources and employment to provide continued sustenance are the bare essentials, but are of no use when individuals do not know how to adequately apply them. Therefore, a system that provides accountability and structure while simultaneously encouraging and facilitating independence and selfsustenance is essential for reentry success.

There are three key policy implications suggested by the present study. The first implication is that there should be more re-entry programming opportunities that offer social support for offenders returning to society as their central component. In addition, programs beyond faith-based organizations need to emphasize the social support component for offenders who want to take part in a support community, but who may avoid doing so because of the religious component of available support systems.

The second policy implication is that parole officers should place more emphasis on connecting recently released offenders to support groups containing successful former offenders. Although offenders in the current study accomplished this primarily through faith-based offender ministries, this does not necessarily mean that parole officers must refer the offender to faith-based ministries. Other potential social support programs include Alcoholics Anonymous, Narcotics Anonymous, and independent post-release support services offered by community-based organizations.

A third policy implication is that partnerships need to be developed between various organizations that either solely focus on providing resources or a support group for recently released offenders in order to provide a more comprehensive treatment plan for those returning to society. 
Although this study has provided useful information regarding successful offender reentry into society, the research is not without limitations. The first limitation of the present study is that all participants were active members of a prison ministry community. These individuals were specifically identified by their respective organizations and were deemed to have successfully reentered society. Therefore, the relative ease reported when seeking the four often-identified resources may be because these individuals were more likely to take the initiative when seeking organization resources, thus increasing their proclivity to be successful. Additionally, the potential exists for the negative impact of the offender stigma decreasing with time, thus increasing an individual's ability to obtain employment with the further passage of time. A second potential limitation is that this study does not include those who have failed, as compared to those offenders viewed as having successfully reentered society. Inclusion of those who failed would provide a stronger backdrop in which to examine why successful individuals are indeed successful. A third potential limitation is that since the majority of these offenders self-identified as being religious, they may have been more inclined to suggest social support as a necessity since community is a large component of most religions. A fourth and final potential limitation is that we did not have enough data regarding in-prison experiences to draw inferences regarding how these experiences may have, if at all, impacted one's likelihood of succeeding or not when reentering society. The role that in-prison experiences play in influencing one's proclivity to successfully reenter society is an important component that needs to be addressed in future research.

From these findings, it is demonstrated that in order for offenders to have a successful reentry, they need to move beyond simply obtaining employment and housing. Additionally, recently released offenders must have a social support system in place to provide a structure and hold them accountable for their actions in a manner different than that provided by parole officers. Struggling with the effects of institutionalization, offenders not only require some sense of structure in their lives, but may also need someone to assist them as they make everyday and oftentimes mundane decisions. This will ensure that offenders do not fall back into old habits or begin associating with old friends involved with criminal behavior, especially with such opportunities present in these often socially and economically deprived communities. Although this study has provided information on successful offender reentry beyond traditionally identified characteristics, future research should continue to examine the relationship between social support and recidivism to better understand its full impact on successful reentry in both faith-based and non-profit organizations.

\section{References}

Baillargeon, J., Hoge, S. K., \& Penn, J. v. (2010). Addressing the challenge of community reentry among released inmates with serious mental illness. American Journal of Community Psychology, 46, 361-375.

Bales, W. D., \& Mears, D. P. (2008). Inmate Social Ties and the Transition to Society Does visitation Reduce Recidivism? Journal of Research in Crime and Delinquency, 45(3), 287-321. 
Belenko, S. (2002). Trends in substance abuse and treatment needs among inmates (final report to the National Institute of Justice). New York, NY: The National Center on Addiction and Substance Abuse at Columbia University.

Belenko, S., \& Peugh, J. (2005). Estimating drug treatment needs among state prison inmates. Drug and Alcohol Dependence, 77, 269-281.

Berg, M. T., \& Huebner, B. M. (2011). Reentry and the ties that bind: An examination of social ties, employment, and recidivism. Justice Quarterly, 28, 382-410.

Cadue, C. (2010). Budget Cuts Challenge Progress Made by States and Elicit Even Smarter Reforms. Corrections Today, 72, 68.

Carson, E. A., \& Sabol, W. J. (2012). Prisoners in 2011. Washington, DC: Bureau of Justice Statistics.

Charmaz, K. (1983). The grounded theory method: An explication and interpretation. In R. Emerson (Ed.), Contemporary Field Research (pp. 109-125). Boston, MA: Little, Brown.

Charmaz, K. (2006). Constructing grounded theory: A practical guide through qualitative analysis. Thousand Oaks, CA: Sage Publications Limited.

Clark, L. M. (2007). Landlord attitudes toward renting to released offenders. Federal Probation,71, 2030.

Cohen, S., \& Syme, S.L. (1985). Issues in the application and study of social support. In S. Cohen \& S.L. Syme (Eds.), Social support and health (pp. 3-22). Orlando, FL: Academic Press.

Corden, J., Kuipers, J., \& Wilson, K. (1978). After prison: A study of the postrelease experiences of discharged prisoners. University of York, Department of Social Administration and Social Work, CPD Unit.

Cowan, D. S., \& Fionda, J. (1994). Meeting the need: the response of local authorities' housing departments to the housing of ex-offenders. British Journal of Criminology, 34, 444-458.

Crayton, A., \& Neusteter, S. R. (2008). The current state of correctional education. Paper presented at the Reentry Roundtable on Education, John Jay College of Criminal Justice, New York, March 31.

Cromwell, P., Alarid, L., \& delCarmen, R. (2005). Community-based corrections (6th ed.). Belmont, CA: Thompson-Wadsworth.

Cullen, F.T. (1994). Social support as an organizing concept for criminology: Presidential address to the Academy for criminal justice sciences. Justice Quarterly, 11, 528-559.

ETS. (2013). Types of literacy. Retrieved from: http://www.ets.org/literacy/research/literacy_types/ 
Fergusson, D., Swain-Campbell, N., \& Hillwood, J. (2004). How does childhood economic disadvantage lead to crime? Journal of Child Psychology and Psychiatry, 45, 956-966.

Garland, B., Wodahl, E. J., \& Mayfield, J. (2011). Prisoner reentry in a small metropolitan community: Obstacles and policy recommendations. Criminal Justice Policy Review, 22, 90-110.

Greenberg, E., Dunleavy, E., \& Kutner, M. (2007). Literacy behind bars: Results from the 2003 National Assessment of Adult Literacy Prison Survey. Washington, DC: National Center for Education Statistics.

Hahn, J. M. (1991). Pre-employment information services: Employers beware. Employee Relations Law Journal, 17, 45-69.

Hammett, T. M., Roberts, C., \& Kennedy, S. (2001). Health-related issues in prisoner reentry. Crime $\mathcal{E}$ Delinquency, 47, 390-409.

Harding, A., \& Harding, J. (2006). Inclusion and exclusion in the re-housing of former prisoners. Probation Journal, 53, 137-153.

Harlow, C. W. (2003). education and correctional populations. Washington, DC: US Department of Justice, Office of Justice Programs.

Helfgott, J. (1997). Ex-offender needs versus community opportunity in Seattle, Washington. Federal Probation, 61, 12-24.

Holzer, H., Raphael, S., \& Stoll, M. (2003, March). employer demand for exoffenders: Recent evidence from Los Angeles. Paper presented at the Urban Institute Roundtable on Offender Re-entry, New York.

Horney, J., Osgood, D.W., \& Marshall, I.H. (1995). Criminal careers in the short-term: Intra-individual variability in crime and its relation to local life circumstances. American Sociological Review, 60, 655-673.

Jucovy, L. (2006). Just out: Early lessons from the Ready4Work Reentry Institute. Field Series Report. Philadelphia, PA: Public/Private ventures.

Kifer, M., Hemmens, C., \& Stohr, M. K. (2003). The goals of corrections: perspectives from the line. Criminal Justice Review, 28, 47-69.

Krivo, L.J., \& Peterson, R.D. (2004). Labor market conditions and violent crime among youth and adults. Sociological Perspectives, 47, 484505.

Kurlychek, M. C., Brame, R., \& Bushway, S. D. (2007). Enduring risk? Old criminal records and predictions of future criminal involvement. Crime \& Delinquency, 53, 64-83. 
Langan, P. A., \& Levin, D. J. (2002). Recidivism of prisoners released in 1994. Federal Sentencing Reporter, 15, 58-65.

La Vigne, N., \& Parthasarathy, B. (2005). Prisoner reentry and residential mobility (Policy brief prepared for the Illinois Criminal Justice Information Authority). Washington, DC: Urban Institute, Justice Policy Center.

LeBel, T. P. (2012). If One Doesn't Get You Another One Will Formerly Incarcerated Persons' Perceptions of Discrimination. The Prison Journal, 92, 63-87.

Levenson, J.S., \& Hern, A.L. (2007). Sex offender residence restrictions: Unintended consequences and community reentry. Justice Research and Policy, 9, 59-74.

Listwan, S. J. (2009). Reentry for serious and violent offenders: An analysis of program attrition. Criminal Justice Policy Review, 20, 154-169.

Luther, J. B., Reichert, E. S., Holloway, E. D., Roth, A. M., \& Aalsma, M. C. (2011). An exploration of community reentry needs and services for prisoners: A focus on care to limit return to high-risk behavior. AIDS Patient Care and STDs, 25, 475-481.

Makarios, M., Steiner, B., \& Travis, L. F. (2010). Examining the predictors of recidivism among men and women released from prison in Ohio. Criminal Justice and Behavior, 37, 1377-1391.

Mallik-Kane, K. (2008). Health and prisoner reentry: How physical, mental, and substance abuse conditions shape the process of reintegration. Washington, D.C.: Urban Institute.

Maruschak, L. M., \& Parks, E. (2012). Probation and Parole in the United States, 2011. U.S. Department of Justice, Office of Justice Programs: Bureau of Justice Statistics.

Mears, D. P., Cochran, J. C., Siennick, S. E., \& Bales, W. D. (2012). Prison visitation and recidivism. Justice Quarterly, 29(6), 888-918.

Meredith, T., Speir, J.C., \& Johnson, S. (2007). Developing and implementing automated risk assessments in parole. Justice Research and Policy, 9, 1-24.

Miles, T. J. (2004). Felon disenfranchisement and voter turnout. The Journal of Legal Studies, 33, 85-129.

National Institute for Literacy. (2001). Fact sheet: Correctional education. Retrieved from www.nifl.gov/newworld/correct.htm

Pager, D. (2003). The mark of a criminal record. American Journal of Sociology, 108, 937-975. 
Pager, D., Western, B., \& Sugie, N. (2009). Sequencing disadvantage: Barriers to employment facing young black and white men with criminal records. The ANNALS of the American Academy of Political and Social Science, 623, 195-213.

Paylor, I. (1995). Housing needs of ex-offenders. Hampshire, UK: Aldershot.

Petersilia, J. (2001). Prisoner reentry: Public safety and reintegration challenges. The Prison Journal, 81, 360-375.

Petersilia, J. (2003). When prisoners come home: Parole and prisoner reentry. New York, NY: Oxford University Press.

Petersilia, J. (2004). What works in prisoner reentry? Reviewing and questioning the evidence. Federal Probation, 68, 4-8.

Petersilia, J. (2005). Hard time: Ex-offenders returning home after prison. Corrections Today, 67, 66-72.

Pettit, B., \& Western, B. (2004). Mass imprisonment and the life course: Race and class inequality in US incarceration. American Sociological Review, 69, 151-169.

Pew Center on the States. (2011). State of Recidivism: The Revolving Door of America's Prisons. Washington, D.C.: The Pew Center on the States.

Raphael, S. (2011). Incarceration and prisoner reentry in the United States. The ANNALS of the American Academy of Political and Social Science, 635, 192-215.

Raphael, S., \& Stoll, M.A., Small, K.A., \& Winston, C. (2001). Can boosting minority car-ownership rates narrow inter-racial employment gaps? Brookings-Wharton Papers on Urban Affairs, 2, 99-137.

Reis, H.T., \& Collins, N. (2000). Measuring relationship properties and interactions relevant to social support. In S. Cohen, L.G. Underwood, \& B.H. Gottlieb (Eds.), Social support measurement and intervention: A guide for health and social scientists (pp. 136-192). Oxford, UK: Oxford University Press.

Rodriguez, M.S., \& Cohen, S. (1998). Social support. In H.S. Friedman (Ed.), encyclopedia of mental health (vol. 3, pp. 535-544). San Francisco, CA: Academic Press.

Rook, K.S., \& Underwood, L.G. (2000). Social support measurement and interventions: Comments and future directions. In S. Cohen, L.G. Underwood, \& B.H. Gottlieb (Eds.), Social support measurement and intervention: A guide for health and social scientists (pp. 311-334). Oxford, UK: Oxford University Press.

Rutter, M. (1987). Psychosocial resilience and protective mechanisms. American Journal of Orthopsychiatry, 57, 316-331. 
Sampson, R.J., \& Raudenbush, S.W. (1999). Systematic social observation of public spaces: A new look at disorder in urban neighborhoods. American Journal of Sociology, 105, 603-651.

Sampson, R.J., Raudenbush, S.W., \& Earls, F. (1997). Neighborhoods and violent crime: A multilevel study of collective efficacy. Science, 227, 916-924.

Sampson, R.J., \& Wilson, W.J. (1995.) Towards a theory of race, crime, and urban inequality. Crime and Inequality, eds. John Hagan and Ruth D. Peterson. Stanford, CA: Stanford University Press.

Seiter, R. P., \& Kadela, K. R. (2003). Prisoner reentry: What works, what does not, and what is promising. Crime \& Delinquency, 49, 360-388.

Solomon, A., Kachnowski, v., \& Bhati, A. (2005). Does parole work? Analyzing the impact of postprison supervision on rearrest outcomes. Washington, DC: Urban Institute.

Spjeldnes, S., \& Goodkind, S. (2009). Gender differences and offender reentry: A review of the literature. Journal of Offender Rehabilitation, 48, 314-335.

Starr, R. (2002). A successful reintegration into the community: One NGRI acquittee's story. Federal Probation, 66, 59-63.

Taxman, F. S., Young, D., Byrne, J.M., Holsinger, A., \& Anspach, D.. (2002). From prison safety to public safety: Innovations in offender reentry. Unpublished grant report (2000-IJ-CX-0045). Washington, D.C.: U.S. Department of Justice.

Tewksbury, R., \& Taylor, J. M. (1996). Consequences of Eliminating Pell Grant Eligibility for Students in Post-Secondary Correctional Education, Programs, Fed. Probation, 60, 60.

The United States Conference of Mayors. (2009). Status of ex-offender reentry efforts in cities: A 79 city survey. Retrieved from: http:// usmayors.org/pressreleases/uploads/ REENTRYREPORT09.pdf

Travis, J. (2005). But they all come back: Facing the challenges of prisoner reentry. Washington, DC: The Urban Institute Press.

Travis, J., Soloman, A. L., \& Waul, M. (2001). From prison to home: The dimensions and consequences of prisoner reentry. Washington, DC: Urban Institute.

Triplett, R.A., Gainey, R.R., \& Sun, I.Y. (2003). Institutional strength, social control and neighborhood crime rates. Theoretical Criminology, 7, 439-467.

Turanovic, J. J., Rodriguez, N., \& Pratt, T. C. (2012). The collateral consequences of incarceration revisited: A qualitative analysis of the effects on caregivers of children of incarcerated parents. 
Criminology, 50, 913-959.

Ulmer, J. T. (2001). Intermediate sanctions: A comparative analysis of the probability and severity of recidivism. Sociological Inquiry, 71, 164193.

U.S. Department of Justice, BJS. (2009). Correctional populations. Retrieved from http://www.bjs.gov/content/glance/tables/corr2tab.cfm

Visher, C., La Vigne, N., Travis, J. (2004). Returning home: Understanding the Challenges of prisoner reentry. Washington, D.C.: Urban Institute, Justice Policy Center.

Visher, C., Winterfield, L., \& Coggeshall, M.B.. (2005). Ex-offender employment programs andrecidivism: A meta-analysis. Journal of experimental Criminology, 1, 295-316.

Warr, M., \& Stafford, M. (1984). Public goals of punishment and support for the death penalty. Journal of Research in Crime and Delinquency, 21, 95-111.

Weiman, D. F. (2007). Barriers to prisoners' reentry into the labor market and the social costs of recidivism. Social Research: An International Quarterly, 74, 575-611.

Wodhal, E. J. (2006). The challenges of prisoner reentry from a rural perspective. Western Criminological Review, 7, 32-47.

Wolff, N., \& Draine, J. (2004). Dynamics of social capital of prisoners and community reentry: Ties that bind? Journal of Correctional Health Care, 10, 457-490.

\section{Contributors}

Andrew S. Denney is a doctoral student in Justice Administration at the University of Louisville. His research focuses on issues of deviance, correctional programming and issues of faith and criminal justice.

Richard Tewksbury is Professor of Justice Administration at the University of Louisville. His research focuses on institutional corrections, correctional management and criminal victimization risks.

Richard Jones is Professor of Social and Cultural Sciences at Marquette University. His research interests center on issues of offender reentry, global perspectives on criminal justice, and the experience of incarceration and criminal justice processing. 


\section{Footnotes}

1. The participant's age and race was not collected, and therefore could not be reported. However, the group was relatively diverse in age and race. $\triangleq$

2. The participants' education level was not recorded. Also, education levels were not explicitly mentioned by any participant in the present study as being a barrier to successful reentry. $\bullet$

3. The sample for the present study mainly consisted of white male exoffenders with higher education, specialized training, and/or more substantial work histories than what prior literature suggests is the case for most ex-offenders. With most of the sample reporting that obtaining employment was not as difficult as prior research leads one to believe, this may help explain why these individuals reported greater overall success obtaining employment. Additionally, this may help explain why these individuals were successful in their re-entry, and yet why employment may remain as a barrier for many ex-offenders today. 